\title{
Resisting Corporate Corruption: Cases in Practical Ethics From Enron Through The Financial Crisis, 2nd Edition. By Stephen V. Arbogast, Wiley-Scrivener, 2013; 552 Pages. Price US \$75.00, ISBN 978-1-118-20855-7
}

\section{Shu-Kun Lin}

MDPI AG, Kandererstrasse 25, CH-4057 Basel, Switzerland; E-Mail: lin@ mdpi.com

Received: 14 May 2013 / Accepted: 15 May 2013 / Published: 22 May 2013

The following paragraphs are reproduced from the website of the publisher [1].

Taking a unique approach to business ethics unlike the typical focus on conceptual/legal frameworks, this book features 25 case studies that cover a full range of business practices, controls, and ethics issues. The new edition is fully updated with new case studies from the recent financial crisis, comparing it with Enron's crossing of various ethical lines. Interpretive essays explore financial control systems and lessons learned from specific case studies and circumstances. Readers will find a practical toolkit they can use to identify ethics issues and tackle problems effectively within corporations.

\section{Table of Contents}

Acknowledgements vii

Preface ix

Note to Faculty:How to Use this Book xvii

Case Study 1 Enron Oil Trading (A): Untimely Problems from Valhalla (A) 5

Essay 1 How to do an Ethics Case Study: Key Steps in Tactical Planning 21

Case Study 2 Enron Oil Trading (B): The Future of Enron InternalAudit 37

Case Study 3 Enron Oil Trading (C): An Opening for EnronAudit? 49

Case Study 4 Enter Mark-to-Market (A): ExitAccounting Integrity? 53

Case Study 5 Enter Mark-to-Market (B): Accounting \& theAggressive Client 71 
Essay 2 NecessaryAmmunition- The Economic Rationale for Financial Control 81

Case Study 6 Enter Mark-to-Market (C): The Disease Spreads to Enron Clean Fuels 107

Case Study 7 Adjusting the Forward Curve in the Back Room (A) 115

Case Study 8 Enron's SPE's:AVehicle too Far? 127

Case Study 9 Court Date Coming in California 149

Case Study 10 Jeff Skilling and LJM (A): The "Shoot the Moon" Meeting 169

Case Study 11 New Counsel forAndy Fastow (A) 189

Case Study 12 Nowhere to Go with "The Probability of Ruin” 205

Case Study 13 Lay Back ... and Say What? 227

Case Study 14 "Whistleblowing” before implodingin Accounting Scandals 249

Essay 3 Legacy and Lessons of Enron: Forerunner of the Financial Crisis? 271

Essay 4 Resisting Corporate Corruption: Tactical Lessons from the Enron Cases 279

Essay 5 Underappreciated Origins of the Financial Crisis:APersonal Memoir 289

Case Study 1 Should Countrywide Join The Subprime Mortgage "Race to the Bottom?" 311

Case Study 2 Seeking a Sustainable Business Model at Goldman Sachs 337

Case Study 3 Juggling Public Policy, Politics and Profits at Fannie Mae (A) 357

Case Study 4 Sub-Prime Heading South at Bear StearnsAsset Management 383

Case Study 5 Ratings Integrity vs. Revenues at Moody's Investors Service 409

Case Study 6 Juggling Public Policy, Politics and Profits at Fannie Mae (B) 437

Case Study 7 Admission of Material Omission? Citibank's SIVs and Sub-Prime Exposure 461

Case Study 8 Facing Reputational Risk on Goldman'sABACUS 2007-AC1 487

Case Study 9 Time to “Drop the Hammer”on AIG's Controls? 505

Case Study 10 Write to Rubin? - Pressure on Underwriting Standards at Citigroup 533

Case Study 11 Wean Lehman Brothers off "Repo 105"? 559

Case Study 12 Time to Report Moody's to the SEC? 575

Case Study 13 Take CitiMortgage to the Feds? 595

Essay 6 Chronic Crises, Systematic Breakdowns, Emerging Resistance and the Implications for Teaching Business Ethics 613

A Note on Sources 629

Index 
* Editor's Note: The brief summary and the contents of the books are reported as provided by the author or the publishers. Authors and publishers are encouraged to send review copies of their recent books of potential interest to readers of Administrative Sciences to the Publisher (Dr. Shu-Kun Lin, Molecular Diversity Preservation International (MDPI), Kandererstrasse 25, CH - 4057 Basel, Switzerland. Tel. +41 6168377 34; Fax: +41 6130289 18, E-mail: lin@ mdpi.org). Some books will be offered to the scholarly community for the purpose of preparing full-length reviews.

\section{Note}

1. The website for this book is: http://www.wiley.com/WileyCDA/WileyTitle/productCd1118208552.html.

(C) 2013 by the author; licensee MDPI, Basel, Switzerland. This article is an open access article distributed under the terms and conditions of the Creative Commons Attribution license (http://creativecommons.org/licenses/by/3.0/). 